\title{
PERAN SENTRAL BUNDA MARIA DALAM PROSESI ARAK- ARAKAN PATUNG TUAN MA DI LARANTUKA (SUATU UNGKAPAN KEARIFAN LOKAL DALAM TRADISI RELIGIUS)
}

\section{CENTRAL ROLE OF MOTHER MARY ON THE PROCESSION OF TUAN MA STATUE IN LARANTUKA (AN EXPRESSIONOF LOCAL WISDOM IN RELIGIOUSTRADITIONS)}

\author{
R.F. Bhanu Viktorahadi \\ Universitas Katolik Parahyangan
}

viktorahadi@yahoo.id

\begin{abstract}
ABSTRAK: Figur Bunda Maria begitu khas bagi masyarakat kota Larantuka yang muncul dalam ritual Semana Santa. Dalam era ini, etnis Lamaholot (pra-Katolik) sistem keagamaan Wulan yang memandang sosok wanita sebagai representasi alam semesta, memunculkan dugaan bahwa ada korelasi dengan dominasi budaya sosok Bunda Maria. Penelitian ini menganalisa prosesi ritual Semana Santa, terutama fenomena arak-arakan tuan Ma sebagai indikator utama apresiasi masyarakat Larantuka dan latar belakang bangsa terhadap Bunda Maria, Masyarakat Larantuka sebagai etnis Lamaholot memiliki kebijaksanaan lingkungan yang disebut Lewotana yang mencakup semua nilai yang mereka merangkul dan menerapkan, yang terdiri dari biaya dalam perangkat keagamaan mereka.Fenomena perubuhan sistem budaya-religi masyarakat Larantuka dari Lewotana dan Lera Wulan Tanah Ekan menjadi budaya Katolik hanyalah terjadi pada tataran perilaku sosial dan artefak, gagasan mengenai nilai akan sakralnya sosok perempuan yang dianggap sebagai representasi alam semesta tetap eksis dalam alam kognitif masyarakat Larantuka dengan figur Bunda Maria sebagai media proses substitusi nilai feminis tersebut serta simbol sebagai 'tempat' makna atas penghormatan terhadap sosok perempuan, khususnya ibu.
\end{abstract}

Kata Kunci : Tuan MA, Semana Santa, Akulturasi, Kearifan Lokal, Feminisme.

ABSTRACT: Saint Mary's figure is so exclusive to the people of Larantuka City which appear in the Semana Santa ritual. In Lera Wulan Tanah Ekan's Lamaholot ethnic pre-Catholic religious system which views female figures as representations of the universe, it brings forth an allegation that there is a correlation with the cultural dominance of the Virgin Mary figure. This paper analyzes Semana Santa's, especially Tuan Ma procession phenomenon as the main indicator of Larantuka society's exclusive appreciation and perception background toward the Virgin Mary and try to seek, Larantuka people as Lamaholot ethnic have a local wisdom called Lewotana covering all the values they embrace and implement, including the value in their religious system. The phenomenon of the cultural system religion of Larantuka society alteration from Lera Wulan Tanah Ekan and Lewotana into Catholic culture only occurs at the level of social behavior and artifacts, the idea of the value of the sacred women figure who is considered as a representation of the universe still exist in the cognitive nature of Larantuka society with the figure of the Virgin Mary as a substitution process media of feminist value along with symbol as 'place' meaning to the admiration and respect to woman figure, especially mother.

Keyword: Tuan Ma, Semana Santa, Akulturasi, Kearifan Lokal, Feminisme. 


\section{A. PENDAHULUAN}

Ritual prosesi perarakan patung Tuan $M a^{1}$ bagi masyarakat Larantuka, Flores Timur sangat istimewa. Proses itu memuat dua nilai sekaligus. Pertama, nilai iman Katolik. Kedua, nilai kearifan lokal, yaitu penghormatan kepada sosok ibu atau perempuan. Sosok Bunda Maria dan perempuan begitu eksklusif bagi masyarakat Kota Larantuka. Hal itu nampak dalam ritual Semana Santa yang datang dari iman Katolik yang mereka anut. Di sisi lain, sistem religi pra-Katolik etnis Lamaholot, yaitu Lewotana dan Lera Wulan Tanah Ekan yang memandang sosok perempuan sebagai representasi alam semesta, memiliki andil dalam terbentuknya dominasi kultural sosok Bunda Maria tersebut. Sebelum datangnya budaya Katolik, masyarakat Larantuka sebagai etnis Lamaholot memiliki nilai budaya dengan Ritual prosesi perarakan patung Tuan $M a^{2}$ bagi masyarakat Larantuka, Flores Timur sangat istimewa. Proses itu memuat dua nilai sekaligus. Pertama, nilai iman Katolik. Kedua, nilai kearifan lokal, yaitu penghormatan kepada sosok ibu atau perempuan. Sosok Bunda Maria dan perempuan begitu eksklusif bagi masyarakat Kota Larantuka. Hal itu nampak dalam ritual Semana Santa yang datang dari iman Katolik yang mereka anut. Di sisi lain, sistem religi pra-Katolik etnis Lamaholot, yaitu Lewotana dan Lera Wulan Tanah Ekan yang memandang sosok perempuan sebagai representasi alam semesta, memiliki andil dalam terbentuknya dominasi kultural sosok Bunda Maria tersebut. Sebelum datangnya budaya Katolik, masyarakat Larantuka sebagai etnis Lamaholot memiliki nilai budaya dengan sebutan Lewotana dan Lera Wulan Tanah Ekan yang mencakup segala nilai yang mereka anut dan implementasikan, termasuk nilai kearifan lokal ${ }^{3}$ dalam sistem religi mereka. Prosesi ritual Semana Santa, terutama perarakan patung Tuan Ma menjadi indikator utama dominasi Bunda Maria dan perempuan pada masyarakat Larantuka.

\footnotetext{
${ }^{1}$ Berdasarkan wawancara dengan Agustinus Siswani Iri, seorang imam Katolik yang bertugas di Larantuka sekaligus penutur bahasa Lamaholot (wawancara dilaksanakan di Bandung pada 1213 Oktober 2019), Tuan Ma berasal dari kata Ema, yang dalam bahasa Lamaholot (bahasa tua Larantuka) memiliki makna perempuan terhormat atau perempuan baik-baik.

${ }^{2}$ Berdasarkan wawancara dengan Agustinus Siswani Iri, seorang imam Katolik yang bertugas di Larantuka sekaligus penutur bahasa Lamaholot (wawancara dilaksanakan di Bandung pada 1213 Oktober 2019), Tuan Ma berasal dari kata Ema, yang dalam bahasa Lamaholot (bahasa tua Larantuka) memiliki makna perempuan terhormat atau perempuan baik-baik.

${ }^{3}$ Abdul Munir Mulkhan, "Pembelajaran Filsafat Berbasis Kearifan Lokal," Jurnal Filsafat vol.17, No.2, Agustus 2007, 145: Kearifan lokal (local wisdom atau local genius) merupakan representasi dan ekspresi pengalaman panjang warga biasa dalam mengelola dan mengatasi berbagai persoalan hidup yang dijalani setiap hari atau pun hari-harinya yang panjang. Kearifan lokal ini meliputi segala aspek kehidupan dari ekonomi, sosial, politik, kesehatan, hingga ketuhanan.
} 
Tulisan ini memaparkan dua rumusan masalah. Pertama, mengungkapkan bagaimana jalannya prosesi ritual Semana santa yang secara tersirat mengandung nilai feminisme. Nilai tersebut terepresentasi dalam sosok Bunda Maria. Deskripsi prosesi ritual itu sekaligus juga mengungkapkan secara singkat sejarah perkembangan Semana santa yang berkaitan dengan proses akulturasi ${ }^{4}$ budaya Lamaholot dengan iman Katolik. Kedua, mengungkapkan bentuk-bentuk dominasi kultural sosok Bunda Maria yang dilatarbelakangi karakteristik dan nilai kearifan lokal Lamaholot (pra-Katolik) yang feminis.

Fenomena perubuhan sistem budaya-religi masyarakat Larantuka dari Lewotana dan Lera Wulan Tanah Ekan menjadi budaya Katolik hanyalah terjadi pada tataran perilaku sosial dan artefak $^{5}$, gagasan mengenai nilai akan sakralnya sosok perempuan yang dianggap sebagai representasi alam semesta tetap eksis dalam alam kognitif masyarakat Larantuka dengan figur Bunda Maria sebagai media proses substitusi ${ }^{6}$ nilai feminis tersebut serta simbol sebagai 'tempat' makna atas penghormatan terhadap sosok perempuan, khususnya ibu.

\section{B. HASIL DAN PEMBAHASAN}

\section{Data Larantuka}

Larantuka adalah sebuah kota kecamatan yang termasuk daerah administrasi Kabupaten Flores Timur (Flotim). Administrasi Daerah dan Kependudukan pembentukan Kabupaten Flotim terjadi pada 20 Desember 1958, yaitu bersamaan dengan ditetapkannya Undang-undang (UU) No. 69 Tahun 1958 tentang Pembentukan Daerah-Daerah Tingkat II dalam Wilayah Daerah-Daerah Tingkat I Bali, NTB, dan NTT. Letak geografis Kabupaten Flores Timur adalah pada $8^{\circ} 04^{\prime}-8^{\circ} 40^{\prime}$ LS dan $122^{\circ} 38^{\prime}-123^{\circ} 20^{\prime}$ BT. Sebelah Utara berbatasan dengan Laut Flores. Sebelah Selatan berbatasan dengan Laut Sawu. Sebelah Timur berbatasan dengan Kabupaten Lembata. Sebelah Barat berbatasan dengan

${ }^{4}$ Koentjaraningrat, Pengantar Ilmu Antropologi (Jakarta: Radar Jaya Offset, 1979), 248: Akulturasi adalah proses sosial yang timbul bila suatu kelompok manusia dengan suatu kebudayaan tertentu dihadapkan dengan unsur-unsur dari suatu kebudayaan asing dengan sedemikian rupa, sehingga unsur-unsur kebudayaan asing itu lambat laun diterima dan diolah ke dalam kebudayaan sendiri tanpa menyebabkan hilangnya kepribadian kebudayaan itu sendiri.

${ }^{5}$ Menurut J.J. Honigmann dalam Koentjaraningrat (1979), 186-188: ada tiga 'gejala kebudayaan', yaitu ideas (gagasan), activities (aktivitas), dan artifacts (artefak). Artefak adalah wujud total dari hasil fisik dari aktivitas, perbuatan, dan karya semua manusia dalam masyarakat, maka sifatnya paling konkret dan berupa benda-benda atau hal-hal yang dapat diraba, dilihat, dan difoto.

${ }^{6}$ William A. Haviland, Antropologi Jilid 2 (Jakarta: Erlangga, 1985), 46: Substitusi adalah bagian dari proses akulturasi yang terjadi saat unsur-unsur kebudayaan yang ada sebelumnya diganti oleh yang memenuhi fungsinya dengan perubahan struktural yang tidak berarti. 
Kabupaten Sikka. Sebagai sebuah Kabupaten kepulauan, Kabupaten Flores Timur memiliki beberapa selat. Antara lain, Selat Lewotobi yang terletak antara Pulau Solor dan Pulau Flores bagian Timur, Selat Gonsalu yang terletak antara Pulau Flores Bagian Timur dengan Pulau Adonara, dan Selat Solor yang terletak antara Pulau Adonara dan Pulau Solor ${ }^{7}$.

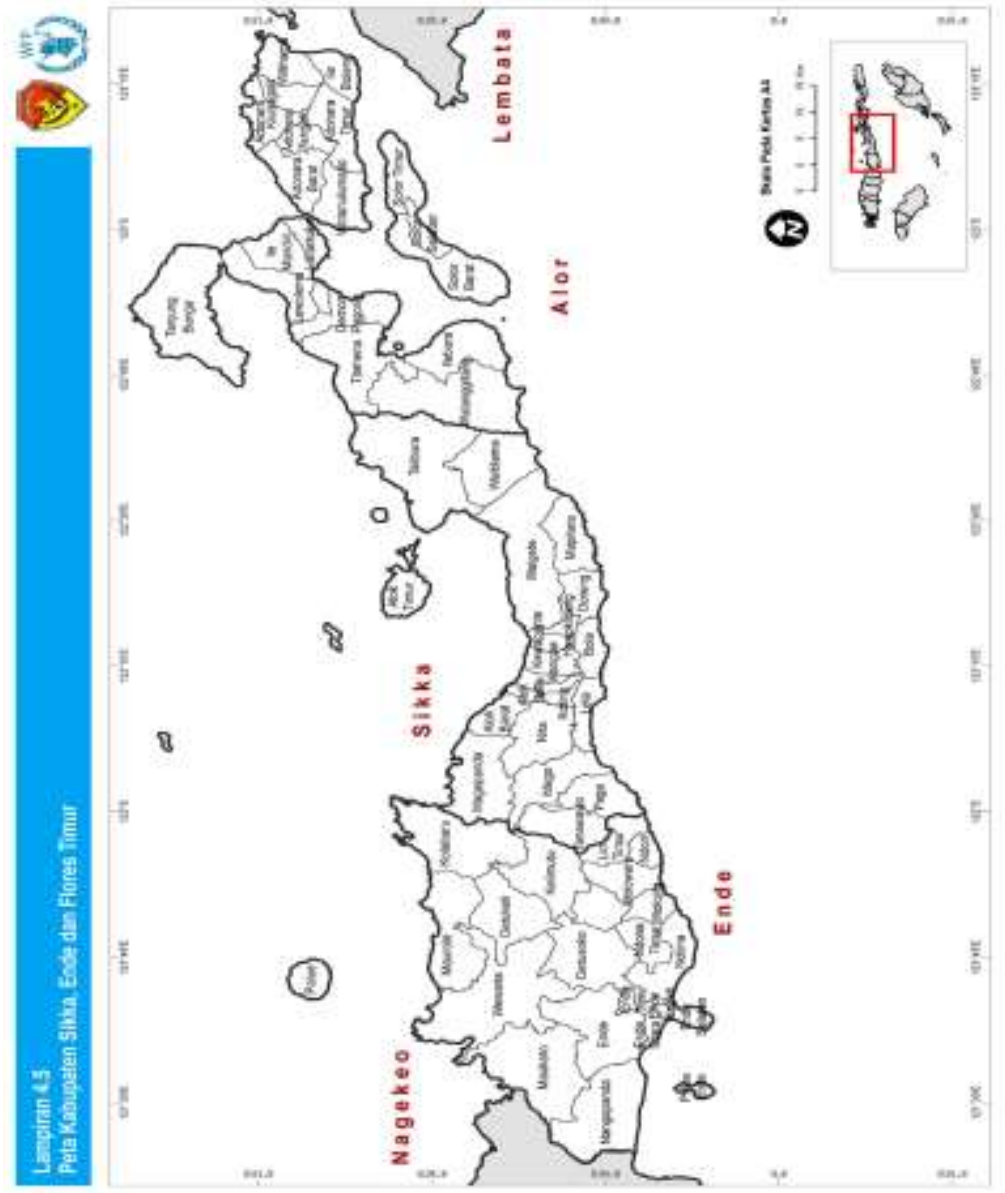

Gambar 1: Peta Kabupaten Flores Timur ${ }^{8}$

Selama kurun waktu 50 tahun terakhir ini sudah beberapa kali terjadi pemekaran wilayah di Kabupaten Flotim. Menurut Provinsi NTT dalam Angka (2006), Kabupaten Flotim yang terdiri atas 13 kecamatan dan 219 desa (kelurahan) mencakup wilayah seluas $1.812,85 \mathrm{~km}^{2}$ atau sekitar 3,83\% dari 47.349,90 $\mathrm{km}^{2}$ (keseluruhan luas daratan Provinsi NTT). Dengan tiga pulau besarnya - Flores Timur Daratan, Pulau Adonara, dan Pulau

\footnotetext{
${ }^{7}$ Profil Kantor Kementerian Agama Kabupaten Flores Timur Tahun 2014, 1-2.

${ }^{8}$ Pemerintah Provinsi Nusa Tenggara Timur Dewan Ketahanan Pangan Kementerian Pertanian World Food Programme, Peta Ketahanan dan Kerentanan Pangan Nusa Tenggara Timur tahun 2015, 171.
} 
Solor - kepadatan penduduk Kabupaten Flotim tergolong tinggi di antara kabupatenkabupaten di NTT, yaitu tertinggi keempat. Di dalam lingkup Kabupaten Flotim sendiri, Pulau Adonara merupakan wilayah terpadat, disusul Pulau Solor. Kepadatan penduduk Flores Timur Daratan tergolong rendah. Merujuk pada sebaran penduduk Kabupaten Flotim terlihat bahwa Kecamatan Ile Boleng (273 orang $/ \mathrm{km}^{2}$ ) di bagian Timur Pulau Adonara justru merupakan kecamatan terpadat, bahkan lebih padat daripada Kecamatan Larantuka (265 orang $/ \mathrm{km}^{2}$ ) dan Kecamatan Adonara Timur (231 orang/km²). Tiga kecamatan yang paling rendah kepadatan penduduknya adalah Kecamatan Titihena, Kecamatan Tanjung Bunga, dan Kecamatan Wulanggitang, yaitu masing-masing 55 orang $/ \mathrm{km}^{2}, 55$ orang $/ \mathrm{km}^{2}$, dan 63 orang $/ \mathrm{km}^{2}$. Dari jumlah penduduk itu, terutama di Kecamatan Larantuka, penduduk beragama Katolik menjadi mayoritasnya (78\%). Oleh karena itu, tradisi setempat, terutama di Larantuka banyak dipengaruhi iman Katolik.

\section{Tradisi Prosesi Tuan Ma dalam Semana Santa}

Bagi masyarakat Larantuka yang mayoritas penganut iman Katolik, Semana Santa atau Pekan Suci ${ }^{9}$ adalah waktu yang istimewa ${ }^{10}$. Aktivitasnya dimulai pada hari Rabu sesudah Minggu Palma, yang disebut dengan nama Rabu Trewa ${ }^{11}$. Malam hari sesudah doa dan Ibadat Lamentasi (ratapan Yeremia) ${ }^{12}$, penduduk Larantuka, membuat kegaduhan dengan bunyi-bunyian dan teriakan 'trewa'. Teriakan ini mengantisipasi suasana kegaduhan peristiwa Yesus yang ditangkap pada keesokan harinya. Sesudah itu mulai masa tenang Semana Santa. Pada hari ini juga penduduk mengadakan kegiatan tikam turo, yaitu mendirikan pagar bambu yang akan dipergunakan sebagai tempat mengikat lilin yang menjadi penerang jalan di sepanjang tiga kilometer jalur prosesi Jumat Agung.

\footnotetext{
${ }^{9}$ Congregatio Pro Cultu Divino, Littera Circulares De Festis Paschalibus Praparandis et Celebrandis (Roma, 16 Januari 1988), 14: Pekan Suci adalah pekan terakhir dalam Masa Prapaskah atau sepekan sebelum Hari Raya Paskah. Dalam Pekan Suci, Gereja merayakan misteri keselamatan yang diwujudkan oleh Yesus Kristus sebagai Mesias pada hari-hari terakhir hidupNya, ketika Ia memasuki Yerusalem.

${ }^{10}$ Rufin Kedang, Tradisi Semana Santa di Larantuka Flores (Melbourne: Oakleigh South, 2017), 2-3.

${ }^{11}$ Rabu Trewa adalah alih bahasa dari bahasa Portugis 'Quarta-feira de trevas'. Artinya, Rabu yang gelap karena tidak lama lagi akan mulai penderitaan Yesus Kristus.

${ }_{12}$ Teks kitab Ratapan 1:4 - Jalan-jalan ke Sion diliputi dukacita, karena pengunjung-pengunjung perayaan tiada; sunyi senyaplah segala pintu gerbangnya, berkeluh kesahlah imam-imamnya; bersedih pedih dara-daranya; dan dia sendiri pilu hatinya.
} 
Aktivitas pada Kamis Putih adalah pembukaan peti patung Tuan Ma (Bunda Maria) dan patung Tuan Ana (Yesus Kristus). Kedua patung itu selama setahun tersimpan di kapelnya masing-masing dan petugas khusus yang diangkat melalui sumpah. Patung Tuan Ma diberi pakaian perkabungan berupa mantel beludru hitam, ungu, atau biru. Sesudah itu umat mendapat kesempatan untuk berdevosi dan berdoa. Selama hari itu juga masing-masing suku penduduk Larantuka sibuk menyelesaikan penataan armida$\operatorname{armida}^{13}$, yaitu delapan tempat perhentian selama prosesi Jumat Agung.

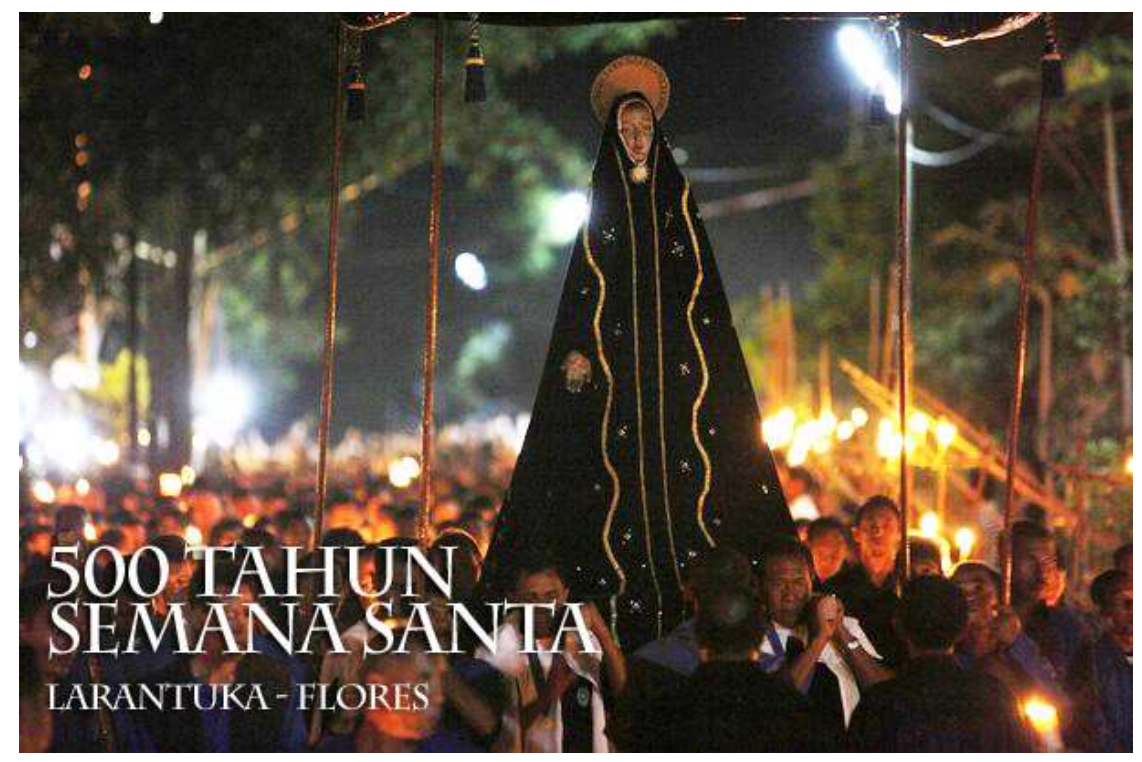

Gambar 2: Patung Tuan $M a^{14}$

Jumat Agung adalah puncak perayaan Semana Santa yang juga dikenal dengan nama upacara Sesta Vera $^{15}$. Secara lengkap puncak prosesi sepanjang Jumat Agung berlangsung dalam tahap-tahapan berikut ini.

13 Armida ini melambangkan perhentian Jalan Salib (via dolorosa), yaitu upacara yang mengenang perjalanan penderitaan Yesus ke puncak Golgota. Tradisi Katolik mengenal 14 titik penderitaan Yesus. Akan tetapi, di Larantuka hanya ada delapan titik yang melambangkan perjalanan Yesus Kristus dari kelahiran hingga wafat-Nya. Ini sekaligus bentuk asimilasi lokal. Delapan armida itu melambangkan delapan suku paling berpengaruh yang dulu memiliki rumat adat tempat penyimpanan patung suci alias korke.

14 http://larantuka2009.blogspot.com/2010/10/peringatan-500-tahun-tuan-ma.html/ diunduh pada Sabtu, 26 Oktober 2019 pk.18.34 WIB.

${ }^{15}$ Sesta Vera adalah alih bahasa dari bahasa Portugis 'Sexta-feira'. Artinya, hari keenam atau Jumat. 
Tabel 2: Jadwal prosesi Tuan Ma ${ }^{16}$

\begin{tabular}{|c|c|c|c|}
\hline No. & Jenis Kegiatan & Waktu & Lokasi \\
\hline 01. & Cium patung Tuan $M a$ & $08.00-11.00$ & $\begin{array}{l}\text { Kapela Tuan Ma Kelurahan } \\
\text { Larantuka }\end{array}$ \\
\hline 02. & Cium patung Tuan Ana & $08.00-11.00$ & $\begin{array}{l}\text { Kapela Tuan Ana Kelurahan } \\
\text { Lohayong }\end{array}$ \\
\hline 03. & $\begin{array}{l}\text { Perarakan patung Tuan } \\
\text { Meninu }\end{array}$ & $08.15-09.45$ & $\begin{array}{l}\text { Kapela Meninu Kelurahan Sarotari } \\
\text { - Armida II Keluarahan Pohonsirih }\end{array}$ \\
\hline 04. & $\begin{array}{l}\text { Perarakan patung Tuan } \\
\text { Misericordice }\end{array}$ & $10.00-11.00$ & $\begin{array}{l}\text { Kapela Tuan Misericordice } \\
\text { Kelurahan Pantebesar - Kapela } \\
\text { Tuan Ana - Armida I Kelurahan } \\
\text { Pohonsirih }\end{array}$ \\
\hline 05. & $\begin{array}{l}\text { Perarakan patung Tuan Ma } \\
\text { dan patung Tuan Ana }\end{array}$ & $13.30-14.30$ & $\begin{array}{l}\text { Kapela Tuan Ana Kelurahan } \\
\text { Lohayong - Kapela Tuan Ma } \\
\text { Kelurahan Larantuka - Gereja } \\
\text { Katedral Kelurahan Postoh }\end{array}$ \\
\hline 06. & Ibadat Jumat Agung & $18.30-20.00$ & Gereja Katedral Kelurahan Postoh \\
\hline 07. & $\begin{array}{l}\text { Perarakan malam Jumat } \\
\text { Agung }\end{array}$ & $\begin{array}{l}\text { 20.00- } 03.00 \\
\text { (Sabtu } \\
\text { Santo) }\end{array}$ & $\begin{array}{l}\text { Gereja Katedral Kelurahan Postoh } \\
\text { mengelilingi kota Larantuka }\end{array}$ \\
\hline
\end{tabular}

Upacara Jumat Agung mencapai klimaksnya pada prosesi di malam hari berkeliling kota Larantuka. Jarak tempuhnya sekitar 7,5 kilometer. Pagi hari usai upacara Jalan Salib, umat berkumpul di Kapel Tuan Meninu (Kanak-kanak Yesus). Patung Kanak-kanak Yesus ditempatkan dalam sebuah perahu dengan tenda penutup atap dan didayung sejauh tiga kilometer menuju pantai Kuce tempat salah satu armida. Banyak sekali perahu dan kapal motor mengiringi pelayaran ini. Di pantai umat berjejal mengikuti prosesi laut ini. Prosesi Jumat Agung dimulai pada pukul delapan malam di Katedral Larantuka sesudah Ibadat Jumat Agung dan berakhir juga di Katedral Larantuka. Lilin-lilin menerangi jalan

16 Agustina Angeliana Belang, Agustina Nurul Hidayati, Endratno Budi Santosa, "Arahan Pengembangan Wisata Religi Kegiatan Prosesi Jumad Agung Kota Larantuka," Jurnal Tata Kota dan Daerah Volume 3, Nomor 1, Juli 2011, 5-6. 
sepanjang jalur prosesi. Ribuan umat ikut dalam prosesi ini yang berlangsung selama empat atau lima jam. Mereka bukan hanya penduduk lokal melainkan juga para peziarah dari luar daerah. Bahkan, ada juga yang datang dari luar negeri. Menurut catatan panitia pada 2017, ada 7.000 peziarah dari luar Larantuka yang hadir.

Yang diusung dalam perarakan itu adalah patung Tuan Ana (Yesus Kristus) diikuti patung Tuan Ma (Bunda Maria). Bunda Maria digambarkan menjemput dan selanjutnya mengikuti anaknya, Yesus dalam perjalanan salib-Nya. Mengawali iringan, seseorang yang berjalan di depan menabuh genderang perkabungan. Genderang ini disebut genda do dengan ritme tertentu. Bunyi ketukannya menimbulkan perasaan gamang. Setelah itu, anak-anak membawa salib hitam dan serai (dua lilin besar). Di belakangnya, satu rombongan membawa lukisan rangka manusia. Namanya, gian de morti. Lukisan ini menyimbolkan godaan setan sepanjang masa. Di rombongan ini ada juga dayabu atau tangan-tangan setan dengan makna yang sama dengan lukisan itu. Selanjutnya adalah rombongan anak-anak yang membawa alat-alat penyengsara Yesus, yaitu krenti (rantai), krona spina (mahkota duri) ${ }^{17}$, tiga batang paku besar dan alat penusuk, tongkat dan bunga karang yang dipakai untuk mencelup cuka yang diminumkan kepada Yesus supaya dapat mati dalam kondisi tak sadar, dan lembing yang merobek lambung Yesus ${ }^{18}$. Selain itu, ada juga tempayan. Tempayan ini melambangkan sifat kemunafikan Pontius Pilatus ${ }^{19}$, wakil pemerintahan Romawi di Yerusalem yang menyerahkan Yesus kepada orang-orang Yahudi yang menyiksanya. Ada pula papan tripleks berbentuk ayam. Ini adalah lambang Petrus $^{20}$, murid Yesus yang sempat menyangkal Yesus setelah gurunya itu ditangkap ${ }^{21}$.

Di belakang iring-iringan itu merayap rombongan inti. Peti mati yang berisi patung Tuan Ana dipikul Lakademu ${ }^{22}$, yaitu petugas dengan muka tertutup kain dan topi

\footnotetext{
${ }^{17}$ Teks Yohanes 19:2-3 - Prajurit-prajurit menganyam sebuah mahkota duri dan menaruhnya di atas kepala Yesus. Mereka memakaikan Dia jubah ungu, dan sambil maju ke depan mereka berkata: "Salam, hai raja orang Yahudi!" Lalu mereka menampar muka-Nya.

${ }^{18}$ Teks Yohanes 19:34 - Tetapi seorang dari antara prajurit itu menikam lambung Yesus dengan tombak, dan segera mengalir keluar darah dan air.

${ }^{19}$ Teks Matius 27:24 - Ketika Pilatus melihat bahwa segala usaha akan sia-sia, malah sudah mulai timbul kekacauan, ia mengambil air dan membasuh tangannya di hadapan orang banyak dan berkata: "Aku tidak bersalah terhadap darah orang ini; Itu urusan kamu sendiri!"

${ }^{20}$ Teks Matius 26:74 - Maka mulailah Petrus mengutuk dan menyumpah: "Aku tidak kenal orang itu." Dan pada saat itu berkokoklah ayam.

21 https://majalah.tempo.co/read/87073/di-larantuka-maria-berdukacita?hidden=login diunduh pada Sabtu, 19 Oktober 2019 pk.12.24 WIB.

${ }^{22}$ Jeverson Peri Maran, "Etnomatemaika dalam Ritus Agama Katolik Larantuka," Prosiding Sendika Vol.5, No.1, 2019, 479: Empat orang yang yang bertugas memikul patung Tuan ana atau
} 
berbentuk kerucut panjang yang dalam tradisi Iberia adalah para penitens ${ }^{23}$ yang melaksanakan aksi tobat ${ }^{24}$. Lakademu ini merupakan orang khusus yang identitasnya dirahasiakan. Yang mengetahuinya hanya raja dan beberapa orang panitia yang ikut menyeleksi ${ }^{25}$. Di belakang patung Tuan Ana ada sejumlah perempuan berpakaian kabung hitam yang melambangkan Perempuan-perempuan Yerusalem yang meratapi Yesus ${ }^{26}$. Patung Tuan Ma dipikul beberapa anggota Konfreria $^{27}$ (persaudaraan), yaitu para petugas gereja yang sudah ratusan tahun keberadaannya. Merekalah yang mempertahankan tradisi dan kelangsungan Gereja Katolik di Larantuka, secara khusus pada masa tidak adanya imam dalam waktu yang panjang.

Tuhan Yesus. Istilah ini merupakan pelafalan lokal dari Nikodemus, salah seorang yang menurunkan jenazah Yesus dari Salib. Namanya terdapat dalam teks Yohanes 19:39 - Juga Nikodemus datang ke situ. Dialah yang mula-mula datang waktu malam kepada Yesus. Ia membawa campuran minyak mur dengan minyak gaharu, kira-kira limapuluh kati beratnya.

${ }^{23}$ Hershey H. Friedman, The Power of Repentance: Penitents (Baalei Teshuvah) of the Talmud and Midrash (New York: Brooklyn College, 2018), 3: The term baal teshuvah (plural is baalei teshuvah) literally means 'master of return', i.e., one who returned to God after being a sinner.

${ }^{24}$ Pakaian seperti ini dipakai juga oleh penitents dalam upacara Semana Santa di Portugal dan Spanyol.

${ }^{25}$ https://www.jawapos.com/features/16/04/2017/cerita-ketika-warga-larantuka-merayakanritual-semana-santa/ diunduh pada Kamis, 17 Oktober 2019 pk.21.07 WIB.

${ }^{26}$ Teks Lukas 23:27-28: Sejumlah besar orang mengikuti Yesus. Di antaranya banyak perempuan yang menangisi dan meratapi Dia. Yesus berpaling kepada mereka dan berkata: "Hai puteri-puteri Yerusalem, janganlah kamu menangisi Aku, melainkan tangisilah dirimu sendiri dan anakanakmu!"

${ }^{27}$ J.A. Sánchez López, Muerte y confradias de passion en la Málaga del siglo XVIII. La imagen procesional del Barroco y su proyección en las mentalidades (Málaga: Universidad de Málaga 1990), 29: Istilah itu bisa diterjemahkan sebagai konfraternitas. Istilah ini menunjuk pada asosiasi keagamaan pertama dengan karakter dan denominasi persaudaraan yang terdaftar dalam dokumentasi yang sesuai dengan abad kesebelas di semenanjung Iberia (Spanyol dan Portugal). Konfreria adalah serikat orang awam yang membantu misionaris Portugis. Mereka bukan imam. pemebentukannya tercatat dalam Conggregatio de Propaganda Fide yang dibentuk Paus Gregorius XV pada 1622. Konfrefia dibentuk supaya masyarakat Larantuka tak bergantung pada misionaris Portugis. Dalam sejarah terbukti, Konfreria sanggup menanggung beban itu. Saat misionaris Portugis meninggalkan Flores dan Pulau Timor pada 1770-an, setelah kolonial Belanda yang menganut Calvinis mengambil alih Larantuka, para anggota Konfreria berhasil mempertahankan prosesi Tuan Ma hingga bertahan saat ini. 


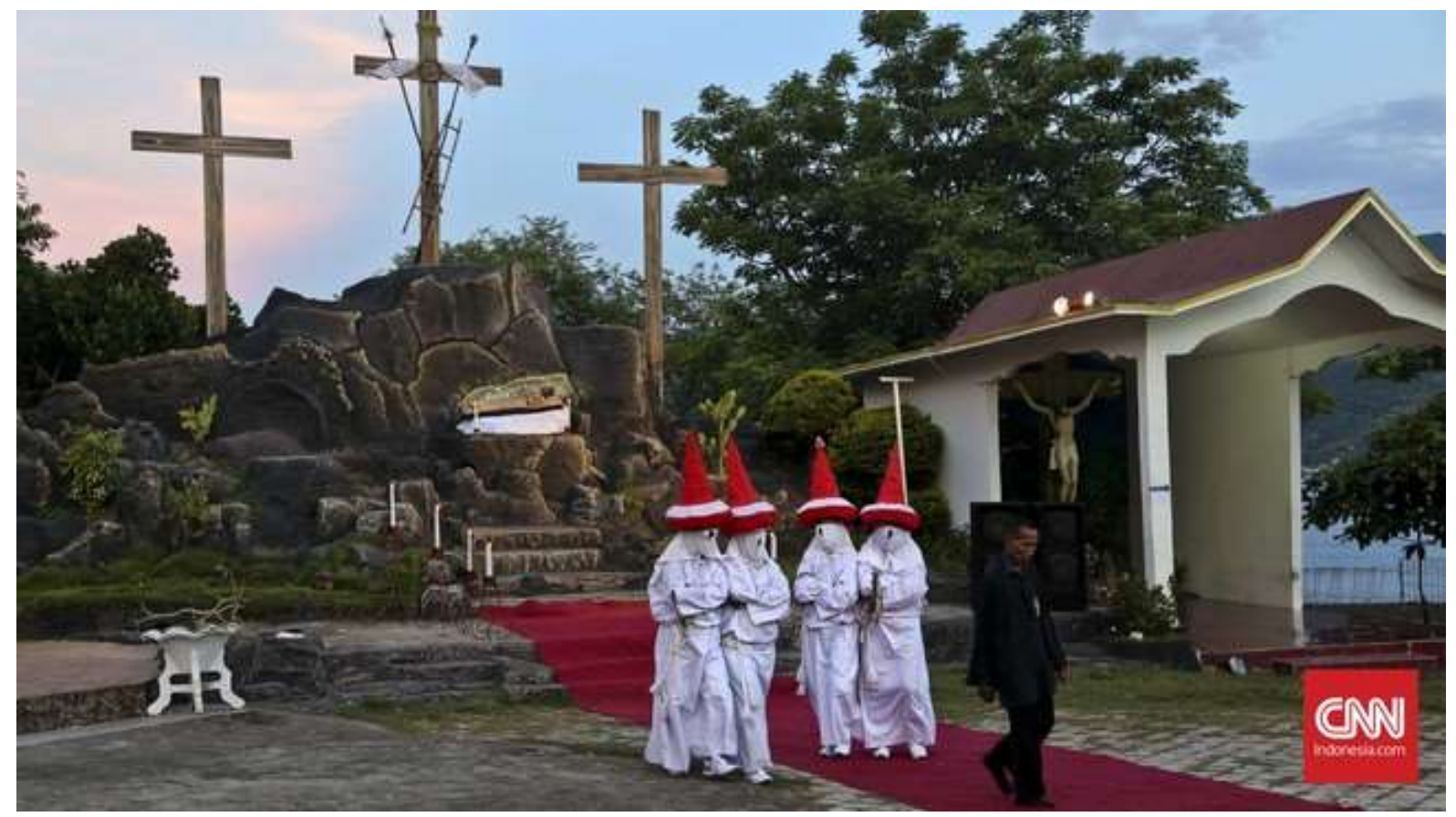

Gambar 3: Lakademu seusai melakukan prosesi di depan Kapel Tuan Ana, Larantuka,

NTT, pada Jumat (25/3). Lakademu adalah orang yang bertugas memandu Keranda

Patung Tuan Ana selama prosesi perarakan pada Malam Jumat Agung. (CNN Indonesia/Adhi Wicaksono) ${ }^{28}$.

Prosesi malam ini menyinggahi delapan armida. Di tiap armida acara meliputi Pentakhtaan Salib, Pembacaan Injil, Doa Tanggapan, dan menyanyikan kidung ' $O$ Vos' ${ }^{29}$ dan 'Signor deo'. Kidung 'Signor deo' dibawakan koor laki-laki dan perempuan. Sedangkan kidung ' $O$ Vos' dibawakan penyanyi tunggal (solis) seorang perempuan yang sambil bernyanyi secara perlahan membuka gulungan gambar Yesus yang bermahkota duri. Penyanyi perempuan itu melambangkan Veronika ${ }^{30}$ yang mengusap wajah Yesus

28 https://www.cnnindonesia.com/gava-hidup/20160326175947-272-119815/kekudusanmalam-jumat-agung-di-larantuka diunduh pada Sabtu, 26 Oktober 2019 pk.18.29 WIB.

${ }^{29}$ Teks lengkap lagu itu diambil dari kitab Ratapan 1:12 dan dinyanyikan dalam bahasa Latin. " $O$ vos omnes qui transitis per viam: attendite et videte si est dolor sicut dolor meus" ("Hai kamu sekalian yang melintas di jalan, perhatikanlah dan lihatlah apakah ada duka seberat dukaku").

${ }^{30}$ Santa Veronika (abad I) adalah seorang perempuan yang mengusap wajah Yesus yang sedang berlumuran darah dengan kerudungnya sehingga wajah Yesus tergambar di kerudungnya. Sebenarnya nama perempuan itu tidaklah diketahui. Di dalam tradisi gereja, ia disebut Veronika sebab dalam bahasa Latin 'Veronika' berarti 'gambar nyata'. Nama itu dikenakan pada perempuan tersebut karena wajah Yesus tergambar di kerudungnya. Veronika dihormati sebagai santa karena ketulusannya dalam meringankan beban Yesus yang sedang menderita di dalam perjalanan menuju penyaliban di Golgota. Dikisahkan bahwa setelah peristiwa tersebut Veronika menjadi seorang Kristen. Sebelum meninggal, ia memberikan kerudung berlumuran darah yang bergambar wajah Yesus itu kepada Paus Klemens. Teks Kitab Suci tidak mencantumkan namanya secara eksplisit. Sejumlah ahli mengatakan bahwa nama Veronika secara implisit terdapat dalam teks Matius 9:20 - Pada waktu itu seorang perempuan yang sudah duabelas tahun lamanya 
yang berdarah dengan kerudungnya sehingga wajah Yesus tergambar di kerudung Veronika (true image). Yang menarik juga dalam kegiatan prosesi ini adalah kehadiran para Remaja Masjid yang bertugas sebagai penjaga keamanan di sekitar katedral.

\section{Riwayat Patung Tuan Ma}

Kepercayaan terhadap $\underline{\text { Tuan } M a}$ berawal lima abad lampau ${ }^{31}$. Berdasarkan penelitian dan sejumlah sumber tertulis dalam bahasa Belanda dan Portugis, patung Tuan Ma ditemukan pada sekitar 1510 di Pantai Larantuka. Diduga, patung itu terdampar saat kapal Portugis atau Spanyol karam di Larantuka. Konon, saat itu seorang anak laki-laki bernama Resiona menemukan patung berwujud perempuan saat mencari siput di Pantai Larantuka. Kala itu, Resiona mengaku melihat perempuan cantik. Ketika ditanya nama serta dari mana datangnya, perempuan tersebut hanya menunduk lalu menulis tiga kata yang tak dipahami Resiona di pasir pantai. Setelah itu, saat mengangkat mukanya, rupa perempuan itu berubah menjadi patung kayu. Ketiga kata yang ditulis itu lalu dibuatkan pagar batu supaya tidak terhapus air laut. Sedangkan patung setinggi tiga meter tersebut langsung diarak keliling kampung, memasuki korke ${ }^{32}$, rumah-rumah pemujaan milik setiap suku di sana.

Kendati waktu itu masyarakat setempat belum mengenal patung tersebut, kepala kampung Lewonama, Larantuka, memerintahkan supaya patung disimpan di korke. Patung kemudian dihormati sebagai benda keramat. Penduduk memberi sesaji setiap perayaan panen. Masyarakat sekitar Larantuka menyebut patung itu sebagai Tuan Ma. Secara harafiah, Tuan Ma berarti tuan dan mama. Masyarakat Lamaholot menyebutnya, Lera Wulan Tanah Ekan. Artinya, Dewa Langit dan Dewi Bumi.

Pada 1650, Raja pertama Larantuka Ola Adobala dibaptis dengan nama Don Andreas Martinho Diaz Vieira Gondinho. Ia menyerahkan Kerajaan Larantuka kepada Bunda Maria. Setelah itu pada 1665 putranya, Raja Don Gaspar I, mulai mengarak patung Maria

menderita pendarahan maju dan mendekati Yesus dari belakang dan menjamah jumbai jubahNya.

${ }^{31}$ Diunduh dari https://www.liputan6.com/regional/read/3422537/hikayat-sakral-kemunculanpatung-tuan-ma-di-pantai-larantuka pada Kamis, 17 Oktober 2019 pk.18.33 WIB.

${ }^{32}$ Koke Bale atau Korke merupakan rumah adat suku Lamaholot di Nusa Tenggara Timur. Istilah Koke Bale sendiri terdiri atas dua kata yakni koke atau boke yang memiliki arti titik pusat dan bale yang berarti tempat tinggal atau rumah. Sehingga, Koke Bale dapat bermakna rumah induk, rumah asal, atau rumah leluhur dari https://kompas.id/baca/nusantara/2018/07/07/rumahadat-koke-bale-pusat-hidup-suku-lamaholot/ diunduh pada Kamis, 17 Oktober 2019 pk.20.49 WIB. 
keliling Larantuka. Dalam perkembangannya, Raja Don Lorenzo I bersumpah kepada Maria atau Tuan Ma dengan memberi gelar tertinggi kepada Maria sebagai ratu orang Larantuka. Oleh karena itu, Larantuka disebut sebagai Kota Reinha (bahasa Portugis) atau Kota Ratu, Kota Maria. Tuan Ma kemudian diyakini sebagai Bunda Maria milik orang Larantuka. Devosi kepada Maria menjadi sentral hidup keluarga dan masyarakat Larantuka. Dalam hal ini, masyarakat Larantuka sangat memercayai adagium Latin, yaitu Per Mariam ad Iesum. Artinya, melalui Maria menuju kepada Yesus. Proses inkulturasi ${ }^{33}$ pun terjadi antara kepercayaan masyarakat lokal, ajaran gereja, dan tradisi yang dibawa Portugis.

\section{Perbedaan intensi prosesi}

Sebenarnya prosesi mengarak patung Maria berduka cita (Maria Adolorata) adalah ritual yang biasa dan wajar dilaksanakan di negara-negara berbudaya Katolik. Misalnya, Italia, Spanyol, dan Portugis. Akan tetapi, tentu saja masing-masing memiliki karakteristik. Karakteristik itu sangat dipengaruhi budaya setempat. Selain karakteristik, masing-masing prosesi juga memiliki penekanan yang berbeda. Salah satu contohnya adalah prosesi arak-arakan patung Maria berduka cita (Maria Adolorata) di Sisilia, Italia.

Tekanan prosesi arak-arakan patung Maria Adolorata di Sisilia terletak pada ratapan $^{34}$. Hampir seluruh Gereja di Sisilia mengiringi arak-arakan jenazah Yesus dengan ratapan yang berasal dari daerah Rafadalli, Sisilia ini. Ratapan ini merupakan lagu arkaik yang melukiskan kesedihan Maria atas wafat Puteranya. Irama ratapan ini naik turun, nyaris mirip dengan alunan orang mengaji yang biasa terdengar dari pengeras suara masjid. Ratapan yang biasanya diteriakkan orang-orang lanjut usia ini merupakan salah satu wajah budaya Arab-Normandia yang masih tertinggal. Banyak umat, terutama yang lanjut usia mencucurkan air matanya saat mendengar lolongan ratapan tersebut. Saat ratapan menggema, dusun itu terasa sangat hening. Suara-suara cerewet dan celoteh

${ }^{33}$ Hans J. Daeng, Upaya Inkulturasi Gereja Katholik Di Manggarai dan Ngada, Flores (Yogyakarta: Disertasi UGM, 1989), 23: Inkulturasi adalah proses yang di dalamnya komunitas Gerejawi menghayati iman dan pengalamannya dalam konteks budaya sedemikian rupa, sehingga hal-hal itu tidak hanya terungkap dalam unsur-unsur budaya lokal, tetapi malahan menjadi kekuatan yang menyemangati, membentuk, dan dengan jelas memperbarui kebudayaan itu seolah-olah menjadi satu ciptaan baru. Sedangkan menurut Paus Yohanes Paulus II dalam Ensiklik Redemptoris Missio No.52, AAS 83 (1991), 300: Inkulturasi adalah transformasi mendalam dari nilai-nilai budaya asli yang diintegrasikan ke dalam kristianitas dan penanaman kristianitas ke dalam aneka budaya manusia yang berbeda-beda.

${ }^{34}$ R.F.B. Viktorahadi Pr., Tujuh Pengalaman Iman dari Tiga Negara (Yogyakarta: Kanisius, 2013), 127-128. 
manusia, semua binasa, seperti mobil yang mesinnya baru dimatikan. Senyap. Angin malam dan angin pagi yang berhembus turut membuat suasana terasa memilukan. Dusun dipenuhi genangan ratapan.

Suasana sedih ini selaras dengan maksud atau intensi peringatan Jumat Agung, yaitu peringatan atau penghadiran kembali sengsara Yesus Kristus. Di dalam ibadat Jumat Agung perhatian utama jemaat yang mengikutinya terarah pada passio atau kisah sengsara Yesus. Secara teologis Konsili Trente ${ }^{35}$ menetapkan bahwa oleh kesengsaraanNya yang kudus pada kayu salib, Yesus memeroleh bagi manusia pembenaran. Sengsara itu sekaligus menekankan keunikan kurban Kristus sebagai 'pokok keselamatan yang abadi bagi semua orang yang taat kepada-Nya ${ }^{36}$. Dalam praktiknya, Gereja atau jemaat yang mengikuti ibadat Jumat Agung itu menghormati salib dengan menyanyikan: “ $O$ crux, ave, spes unica! - Salam, o salib suci, engkaulah harapan dunia ini satu-satunya!"37

Singkatnya, dalam ibadat Jumat Agung yang biasa dirayakan jemaat Katolik di seluruh dunia, sosok utamanya adalah Yesus. Bunda Maria menjadi sosok sekunder dalam kapasitasnya sebagai pengantara kepada Sang Putera, yaitu Yesus itu sendiri. Ini seperti yang diungkapkan dalam adagium Latin, yaitu Per Mariam ad Iesum. Artinya, melalui Maria menuju kepada Yesus.

\section{Kearifan lokal Larantuka}

Pada masyarakat atau jemaat Katolik Larantuka, nampaknya sosok Bunda Maria mendapat peran yang lebih sentral dalam ibadat Jumat Agung. Itu tercermin dalam prosesi perarakan patung Tuan Ma. Diduga kuat, hal ini dipengaruhi nilai kearifan lokal yang dimiliki masyarakat Larantuka. Selain budaya Katolik yang memang sangat menghormati Bunda Maria, ideologi mengenai sosok perempuan sebagai representasi alam semesta dalam nilai budaya etnis Lamaholot (penghuni awal Larantuka) yang dikenal dengan sebutan Lewotana menjadi temuan penting dalam mengkaji fenomena dominasi kultural sosok Bunda Maria. Sistem religi awal masyarakat Larantuka Lera Wulan Tana Ekan juga memiliki andil. Sistem religi itu memercayai adanya roh dan mahkluk gaib yang memengaruhi kehidupan manusia. Salah satunya adalah Tonu Wujo yang dipercaya

\footnotetext{
${ }^{35}$ Konsili Trente, Decretum de iustificatione DS 1529: Sua sanctissima passione in ligno crucis nobis iustificationem meruit.

${ }^{36}$ Surat kepada Orang Ibrani 5:9.

37 Congregatio Pro Cultu Divino, Additio liturgica ad Hymnum 'Vexilla Regis': Liturgia Horarum, editio typica (Roma: Typis Polyglottis Vaticanis, 1974), 313.
} 
sebagai dewi kesuburan. Etnis Lamaholot sangat mengagumi dan menghormati Tonи Wujo sebagai dewi kesuburan. Hal inilah yang menyebabkan mengapa hadirnya patung Tuan Ma (Bunda Maria) dulu dianggap sebagai kehadiran Tonu Wujo dalam bentuk lain ${ }^{38}$.

Sosok Bunda Maria memiliki implikasi yang masif pada masyarakat Larantuka. Hal ini nampak pada ideologi masyarakat lokal yang menjadikan Bunda Maria sebagai ratu pelindung Kota Larantuka. Sosok suci yang menjadi panutan bagi para perempuan Larantuka, khususnya ibu dalam menjalani kehidupannya. Indikasi dominasi sosok Bunda Maria dapat ditemukan dalam gagasan, perilaku sosial yang dilakukan dengan sadar maupun tidak, dan artefak pada konstruksi sistem sosio-kultural masyarakat Larantuka. Hal tersebut lebih nampak pada ritual Semana Santa yang memang secara eksplisit diselenggarakan sebagai rasa hormat terhadap sosok Bunda Maria. Konfreria atau Laskar Maria menjadi pihak penyelenggara utama sekaligus pelestari ritual ini ${ }^{39}$.

Fenomena perubahan dalam budaya masyarakat Larantuka dari pra-Katolik menuju Katolik hanyalah pada tataran perilaku sosial dan artefak. Jika dilihat dengan teliti, nilai budaya masyarakat Larantuka mengenai penghormatan terhadap sosok perempuan atau seorang ibu tidak berubah. Nilai tersebut tetap eksis yang secara simbolik terepresentasi oleh sosok Bunda Maria. Begitu kuat kebaktian masyarakat Larantuka kepada Bunda Maria sehingga Raja Larantuka sendiri memberi gelar 'Maria Reinha Larantuka' kepada Bunda Maria. Konsep ini lahir dari suatu pengalaman antropologis manusiawi bahwa seorang ibu memenuhi kebutuhan anaknya. Hubungan krusial tersebut lantas dikaitkan dengan hubungan antara manusia dengan alam. Bumi dan alam raya beserta isinya (Mother Earth atau Mother Nature) menyediakan kebutuhan-kebutuhan kehidupan manusia.

Gagasan tentang suatu kosmos atau jagad yang hidup tersebut sejalan dengan sistem religi mereka, yaitu Lera Wulan Tanah Ekan. Lera Wulan berarti 'matahari-bulan' lalu digabungkan menjadi satu kata yang berarti 'langit'. Sedangkan Tana Ekan berarti 'bumi'. Sistem kepercayaan mereka ini berangkat dari keyakinan dan kekaguman mereka akan adanya kekuatan yang dimiliki alam atau kosmos. Alam semesta dilihat sebagai

\footnotetext{
${ }^{38}$ Abima Narasatriangga, Purwadi, I Nyoman Dhana, "Dominasi Kultural Figur Bunda Maria Dalam Ritual Semana Santa Pada Masyarakat Larantuka, Flores Timur," Jurnal Humanis, Fakultas Ilmu Budaya Unud Vol 22.4, November 2018, 937.

${ }^{39}$ Fransiskus Emanuel da Santo, Hari Bae di Nagi Tana - Pekan suci di Larantuka (Larantuka: Komisi Kateketik Keuskupan Larantuka, 2010), 33.
} 
sesuatu yang sakral sehingga dianggap memiliki jiwa atau roh. Mereka juga percaya bahwa benda-benda alam seperti batu atau pohon-pohon besar sebagai tempat tinggal rohroh para leluhur mereka ${ }^{40}$.

Atas dasar nilai budaya Lewotana dan sistem religi Lera Wulan Tanah Ekan tersebut, orang Lamaholot sangat menghormati lingkungannya. Alam raya dipandang sebagai sesuatu yang sakral yang telah memberikan mereka kehidupan juga sebagai tempat rohroh atau jiwa leluhur mereka yang sudah meninggal dunia. Keberlangsungan dan kebutuhan hidup mereka, termasuk kebutuhan papan-pangan-sandang dan lainnya berasal dari alam sekitar. Menurut Agustinus Iri, seorang imam Katolik yang bertugas di Larantuka $^{41}$, orang Lamaholot memandang sosok perempuan atau ibu itu sebagai manifestasi dari alam raya. Sedangkan figur laki-laki adalah representasi seorang raja atau pemimpin yang harus memperlakukan alam sekitarnya dengan bijaksana. Hal tersebut lalu berkorelasi dalam kehidupan suami-istri. Istri sekaligus seorang ibu yang secara ideal senantiasa menjadi 'sumber kehidupan' anak dan juga suaminya.

Etnis Lamaholot adalah masyarakat dengan orientasi berpikir yang feminis. Hal ini dapat ditegaskan dengan cerita rakyat (folklore) dan mitologi mereka mengenai manusia pertama, yaitu seorang perempuan bernama Watowele yang dikisahkan terlahir dari sebuah batu di Gunung Ile Mandiri. Gagasan tersebut merupakan bagian dari sistem religi etnis Lamaholot Lera Wulan Tanah Ekan. Kemudian diperkuat dengan adanya sosok supranatural yang bernama Tonu Wujo yang juga sosok perempuan ${ }^{42}$. Tonu Wujo adalah sesosok dewi kesuburan yang disakralkan, disembah, dan diselenggarakan ritual baginya dalam kaitannya dengan sektor pertanian. Pada kelompok etnis Lio di kabupaten Ende, gadis ini dimitoskan sebagai pemberi padi bernama Ine Mbu atau Ina Pare. Sedangkan di Ata Baolangu, Lembata perempuan ini dikenal dengan Ina Peni dan di Tana 'Ai, Maumere dikenal sebagai Du'a Pare' Wai Nalu' ${ }^{43}$.

40 Oktovianus Sila Wuri Subanpulo, "Pengaruh Budaya Lamaholot dalam Ruang Kota Larantuka," Jurnal Pembangunan Wilayah dan Kota, Biro Penerbit Planologi Undip vol.8 (3), September 2012, 251.

${ }^{41}$ Wawancara dilaksanakan di Bandung pada 12-13 Oktober 2019.

${ }^{42}$ Yoseph Yapi Taum, Kisah Watowele-Lia Nurat dalam Tradisi Puisi Lisan Flores Timur (Jakarta: Yayasan Obor Indonesia dan Yayasan Asosiasi Tradisi Lisan, 1997), 243-245.

${ }^{43}$ K.H. Kohl, Der Tod der Reisjungfrau, Mythen, Kulte und Alianzen in Einer Ostindonesischen Lokalkultur, Terjemahan: Raran Tonu Wujo: Aspek-aspek Inti Sebuah Budaya Lokal di Flores Timur oleh Paul Sabon Nama (Maumere: Penerbit Ledalero, 2009), 146. 
Menurut Agustinus Iri, terutama setelah hadirnya patung jelmaan Tonu Wujo (yang sebenarnya adalah patung Tuan Ma) di Larantuka, ikatan emosional dan psikologis antara orang Lamaholot dengan Tonи Wujo kuat dan intim. Eksistensi Tonu Wujo sangat krusial. Keadaan itu terus berlangsung hingga misionaris Portugis memperkenalkan Bunda Maria sekaligus menjelaskan bahwa patung jelmaan Tопи Wијo itu adalah patung Bunda Maria.

Berkat kearifan lokal dalam diri sosok Tonu Wujo itu masuknya unsur budaya Katolik yang memiliki sosok Perawan Suci Maria tidak mengalami banyak hambatan. Kisah hidup Bunda Maria yang mengisahkan sifat-sifat mulianya pun mendukung proses penerimaan gagasan baru bagi etnis Lamaholot. Gagasan baru ini membentuk 'versi baru' Tonu Wujo dalam wujud Bunda Maria. Gagasan baru itu semakin nampak dengan adanya fenomena patung Tuan Ma yang sebelum kedatangan para misionaris dianggap masyarakat pra-Katolik Larantuka sebagai jelmaan sosok Tonи Wujo. Pandangan ini mempermudah budaya Katolik masuk mensubstitusi sosok Tonu Wujo dengan Bunda Maria. Substitusi itu semakin mudah berkat citra Bunda Maria yang penuh dengan kasih sayang, ketabahan, dan penuh perjuangan, selaras dengan dengan nilai kearifan lokal budaya Lamaholot yang sangat feminis.

Sebenarnya nilai kearifan lokal budaya Lamaholot yang sangat feminis ini dapat dipandang sebagai praktik-praktik maternal yang didasarkan pada kepentingan merawat dan membesarkan. Tujuan dari praktik-praktik maternal ini bukanlah dominasi dan penaklukan, melainkan mengadakan keseimbangan dalam relasi, melakukan perawatan, penumbuhan, dan pengembangan. Dalam praktik-praktik maternal, anak tidak dilihat sebagai suatu dualisme seperti yang dikemukakan teori Descartes, yaitu adanya badan (fisik) dan adanya mind (jiwa-rohani). Akan tetapi, bagi intuisi maternal, badan dan mind atau jiwa seorang anak merupakan kesatuan dengan dirinya yang berdasarkan maternal spirit yang terus hidup dan berkembang ${ }^{44}$.

Menurut Sara Ruddick ${ }^{45}$, pendasaran moral dan nilai-nilai maternal dapat menyelesaikan hal-hal penting. Misalnya, kekerasan dan ketidakadilan yang sering dijumpai dalam konflik atau peperangan, baik di tingkat domestik maupun publik.

\footnotetext{
${ }^{44}$ Andrea Nye, Philosophy and Feminism (New York: Twyne Publishers, 1995), 49.

${ }^{45}$ Sara Ruddick, "Maternal Thinking," Women and Values, Marilyn Pearsall (ed.) (California: Wadsworth Publishing Company, 1993), 396.
} 
Menurutnya, maternal thinking menebarkan harapan dan kedamaian. Nilai-nilai filosofis inilah yang terdapat dalam kearifan lokal masyarakat Larantuka yang feminis.

\section{SIMPULAN}

Prosesi perarakan patung Tuan Ma yang adalah bagian dari Semana Santa menjadi sarana pengungkapan dua nilai yang dimiliki masyarakat Larantuka, yaitu nilai iman atau religiusitas dan nilai kearifan lokal pra-Katolik yang feminis. Hal itu terjadi dalam proses akulturasi budaya, tradisi iman Katolik merasuki nilai kearifan lokal setempat. Nilai kearifan lokal yang menempatkan sosok perempuan dalam diri Tonи Wujo mendapat tempat yang pas dalam sosok Bunda Maria (Tuan Ma). Kearifan lokal yang feminis ini menjadi pintu masuk bagi sosok Bunda Maria. Pandangan ini mempermudah budaya Katolik masuk mensubstitusi sosok Tonи Wujo dengan Bunda Maria. Substitusi itu semakin mudah berkat citra Bunda Maria yang penuh dengan kasih sayang, ketabahan, dan penuh perjuangan, selaras dengan nilai kearifan lokal budaya Lamaholot yang sangat feminis. Akan tetapi, jika dibandingkan dengan intensi utama ritual Semana Santa atau Pekan Suci yang umum diyakini Gereja Katolik, terjadi pergeseran intensi penokohan. Gereja Katolik menempatkan Yesus sebagai tokoh atau sosok sentral dari ritual Pekan Suci atau Jumat Agung secara khusus. Sedangkan, jika dilihat dari praktik ritual, terutama prosesi perarakan patung Tuan Ma ditambah dengan pengaruh kearifan lokal yang feminis, nampaknya masyarakat Larantuka lebih menempatkan sosok Bunda Maria sebagai sentralnya. Dalam hal ini, prosesi perarakan patung Tuan Ma memberi tempat lebih sentral bagi kearifan lokal dibandingkan bagi nilai religiusitas.

\section{DAFTAR PUSTAKA}

Bachtiar, Palmira Permata. Sulton Mawardi. Deswanto Marbun. Iklim Usaha di Kabupaten Flores Timur (Flotim): Kajian Kondisi Perekonomian dan Regulasi Usaha. Jakarta: Lembaga Penelitian SMERU, 2014.

Bala, Kristoforus. Santa Maria Ratu Rosario sebagai Bintang Misi-Evangelisasi di Nusa Tenggara (Malang: Seri Filsafat dan Teologi, Vol. 25 No. Seri 24, 2015), 98-148.

Belang, Agustina Angeliana. Agustina Nurul Hidayati. Endratno Budi Santosa. "Arahan Pengembangan Wisata Religi Kegiatan Prosesi Jumad Agung Kota Larantuka." Jurnal Tata Kota dan Daerah Volume 3, Nomor 1, Juli 2011, 1-10.

Congregatio Pro Cultu Divino, Additio liturgica ad Hymnum 'Vexilla Regis': Liturgia Horarum, editio typica. Roma: Typis Polyglottis Vaticanis, 1974. , Littera Circulares De Festis Paschalibus Praparandis et Celebrandis. Roma, 16 Januari 1988.

da Santo, Fransiskus Emanuel. Hari Bae di Nagi Tana - Pekan suci di Larantuka. Larantuka: Komisi Kateketik Keuskupan Larantuka, 2010. 
Daia, Willem. Menanggapi Harta Rohani Bersama Bunda Maria. Yogyakarta: Yayasan Pustaka Nusatama, 2001.

Daeng, Hans J. Upaya Inkulturasi Gereja Katholik Di Manggarai Dan Ngada, Flores. Yogyakarta: Disertasi UGM, 1989.

Friedman, Hershey H. The Power of Repentance: Penitents (Baalei Teshuvah) of the Talmud and Midrash. New York: Brooklyn College, 2018.

Gusmão, Martinho G. da Silva. Menantikan Loro-sae: Refleksi Peziarahan Gereja bersama Masyarakat Timor Timur. Malang: Study Group Fraters Timor Timur, 1997.

Haviland, William A. Antropologi Jilid 2. Jakarta: Erlangga, 1985.

Jebarus, E. 125 Tahun Gereja Katedral Larantuka. Maumere: Penerbit Ledalero, 2011.

Kedang, Rufin. Tradisi Semana Santa di Larantuka Flores. Melbourne: Oakleigh South, 2017.

Koentjaraningrat, Pengantar Ilmu Antropologi. Jakarta: Radar Jaya Offset, 1979.

Kohl, K.H. Der Tod der Reisjungfrau, Mythen, Kulte und Alianzen in Einer Ostindonesischen Lokalkultur, Terjemahan: Raran Tonu Wujo: Aspek-aspek Inti Sebuah Budaya Lokal di Flores Timur oleh Paul Sabon Nama. Maumere: Penerbit Ledalero, 2009.

Konsili Trente, Decretum de iustificatione DS 1529.

Maran, Jeverson Peri. "Etnomatemaika dalam Ritus Agama Katolik Larantuka." Prosiding Sendika Vol.5, No.1, 2019, 473-480.

Martasudjita, E. Ekaristi. Yogyakarta: Kanisius, 2011.

Mulkhan, Abdul Munir. "Pembelajaran Filsafat Berbasis Kearifan Lokal." Jurnal Filsafat vol.17, No.2, Agustus 2007, 133-149.

Narasatriangga, Abima. Purwadi. I Nyoman Dhana. "Dominasi Kultural Figur Bunda Maria Dalam Ritual Semana Santa Pada Masyarakat Larantuka, Flores Timur." Jurnal Humanis, Fakultas Ilmu Budaya Unud Vol 22.4 November 2018, 935-942.

Nye, Andrea. Philosophy and Feminism. New York: Twyne Publishers, 1995.

Pemerintah Provinsi Nusa Tenggara Timur Dewan Ketahanan Pangan Kementerian Pertanian World Food Programme, Peta Ketahanan dan Kerentanan Pangan Nusa Tenggara Timur tahun 2015.

Profil Kantor Kementerian Agama Kabupaten Flores Timur Tahun 2014.

Ratri, Maria Monika. Doa-doa Devosi. Jakarta: Obor, 2003.

Ruddick, Sara. "Maternal Thinking," Women and Values, Marilyn Pearsall (ed.). California: Wadsworth Publishing Company, 1993.

Sánchez López, J.A. Muerte y confradias de passion en la Málaga del siglo XVIII. La imagen procesional del Barroco y su proyección en las mentalidades. Málaga: Universidad de Málaga, 1990.

Subanpulo, Oktovianus Sila Wuri. "Pengaruh Budaya Lamaholot dalam Ruang Kota Larantuka." Jurnal Pembangunan Wilayah dan Kota, Biro Penerbit Planologi Undip vol.8 (3), September 2012, 247-256.

Taum, Yoseph Yapi. Kisah Watowele-Lia Nurat dalam Tradisi Puisi Lisan Flores Timur. Jakarta: Yayasan Obor Indonesia dan Yayasan Asosiasi Tradisi Lisan, 1997.

Viktorahadi Pr., R.F.B. Tujuh Pengalaman Iman dari Tiga Negara. Yogyakarta: Kanisius, 2013.

Yohanes Paulus II, Ensiklik Redemptoris Missio No.52, AAS 83 (1991). 


\section{Tautan internet:}

https://www.liputan6.com/regional/read/3422537/hikayat-sakral-kemunculan-patungtuan-ma-di-pantai-larantuka diunduh pada Kamis, 17 Oktober 2019 pk.18.33 WIB. https://kompas.id/baca/nusantara/2018/07/07/rumah-adat-koke-bale-pusat-hidup-sukulamaholot/ diunduh pada Kamis, 17 Oktober 2019 pk.20.49 WIB.

https://www.jawapos.com/features/16/04/2017/cerita-ketika-warga-larantukamerayakan-ritual-semana-santa/ diunduh pada Kamis, 17 Oktober 2019 pk.21.07 WIB.

https://majalah.tempo.co/read/87073/di-larantuka-maria-berdukacita?hidden=login diunduh pada Sabtu, 19 Oktober 2019 pk.12.24 WIB.

https://www.cnnindonesia.com/gaya-hidup/20160326175947-272-119815/kekudusanmalam-jumat-agung-di-larantuka diunduh pada Sabtu, 26 Oktober 2019 pk.18.29 WIB.

http://larantuka2009.blogspot.com/2010/10/peringatan-500-tahun-tuan-ma.html/ diunduh pada Sabtu, 26 Oktober 2019 pk.18.34 WIB. 